\title{
EURÍPIDES ARISTOFÂNICO: A TRAGÉDIA COMO ARTIFÍCIO CÔMICO
}

\author{
ANA MARIA CÉSAR POMPEU \\ Universidade Federal do Ceará
}

\begin{abstract}
Resumo: Em Acarnenses, Aristófanes se servirá do Télefo de Eurípides para se defender como poeta cômico e como protagonista; tal modelo será retomado em Tesmoforiantes, na necessidade de um novo disfarce, o feminino. Novamente quando a tragédia estava no Hades, e a cidade precisava de uma salvação, o deus Dioniso se travestirá de Héracles para resgatar Eurípides, que, embora substituído por Ésquilo, será a motivação do resgate da tragédia no mundo dos mortos, em Rãs. Aristófanes, fazendo a crítica e assimilando os artifícios da tragédia de Eurípides, o poeta das inúmeras soluções, estabelece os limites de sua própria comédia e se distingue como poeta e pensador na Atenas da segunda metade do século V.
\end{abstract}

Palavras-chave: Eurípides, Aristófanes, Télefo, Disfarce, Artifícios.

Eurípides está presente em toda a obra aristofânica, mesmo quando de forma mais sutil. Em três peças, no entanto, o tragediógrafo se torna personagem na comédia de Aristófanes: Acarnenses, Tesmoforiantes e Rãs. Por considerarmos Acarnenses um paradigma da comédia antiga, uma vez que o comediógrafo parece ter tido motivos para apresentar uma espécie de programação para o seu discurso cômico, tendo sido acusado de falar mal da cidade diante de estrangeiros, ela será a peça chave para o que vamos discutir nas duas outras.

\section{Acarnenses}

Por que Aristófanes escolhe Eurípides como o representante da tragédia nesta sua peça que apresenta o programa que o jovem poeta cômico parece traçar para a sua obra? No monólogo inicial do protagonista, dentre suas dores, ele apresenta a ocasião em que estava à espera de Ésquilo, mas Teógnis é que foi anunciado para apresentar sua tragédia. Ésquilo era uma referência e suas peças continuavam a ser encenadas, mesmo após a sua morte. Eurípides não é citado no monólogo, 
uma vez que não figuraria entre os maus poetas nem seria uma referência de bom poeta dos tempos de Ésquilo; mas algumas palavras e expressões de Diceópolis parecem ser citações do Télefo de Eurípides. Uma dessas expressões era atribuída a Aquiles na peça ${ }^{1}$ e leva Platter (2007, p. 53-4) a interpretar que Diceópolis nesse momento sente-se, como Aquiles, o algoz de Télefo, forte e destemido, ao falar com o suplicante inimigo. É interessante pensar que aqui o protagonista faz o papel de espectador, que critica o que vê, sem nada temer. E o momento determinado é o da comédia do ano anterior, em que derrotava o seu inimigo Cléon. Mas, ao ser acusado por ele nessa mesma peça - Babilônios -, o autor cômico passou a ser o acusado e teria que se defender. Acarnenses traz o enredo de acordo com a necessidade de defesa, colocando o protagonista em maus lençóis por ter feito tréguas com o inimigo espartano. Télefo era mesmo a personagem que melhor se encaixava como disfarce para a defesa do poeta e do protagonista.

O Télefo de Aristófanes quebra a ilusão dramática e o páthos de que a tragédia depende, pois, enquanto o Télefo de Eurípides não se disfarça no palco, mas parece entrar disfarçado, de acordo com Foley (1996, 135-7), o espectador de Aristófanes vê Diceópólis vestir os trapos de Télefo e começar a se comportar como um mendigo; já na cena de aquisição dos acessórios do disfarce, pelo exagero do detalhe e da atuação de Diceópolis torna-se demasiadamente realístico e não trágico. Também por expor o mecanismo do ekkýklema (408), no momento em que Diceópolis chama Eurípides para fora de casa, pode sugerir que a comédia desmascara o gênero sério, mostrando os bastidores do teatro trágico, mas acrescentando o mesmo mecanismo a sua própria ilusão cômica. Se o disfarce era para causar compaixão aos acarnenses, como ele poderá funcionar sem o páthos trágico? Télefo era um herói grego que se tornou um rei mísio, pelas manobras do destino. Quando se faz conhecer como um grego diante dos demais e ainda se oferece como guia para Tróia, em troca de sua cura por Aquiles, há o consenso geral dos aqueus em ajudá-lo. O seu disfarce de mendigo na peça de Eurípides retrata a sua condição de suplicante diante dos gregos e sua identidade confusa. No final de Acarnenses, é Lâmaco que parece assumir a figura de Télefo, quando volta ferido de uma expedição militar, na narrativa do mensageiro, parodiada da tragédia, possivelmente Télefo: Lâmaco foi ferido por uma estaca que apoia videiras; enquanto Télefo teria

1 Áxion gàr Helládi ' pois é digno da Grécia'. Em Acarnenses 8, Diceópolis se refere ao feito heróico dos cavaleiros, quando obrigaram Cléon a vomitar os cinco talentos; em Télefo fr. 720 N2, Aquiles estaria se referindo a alguém (Télefo, Helena, Páris?) que, se tivesse um fim trágico, seria digno da Grécia. 
sido emaranhado em videiras, quando foi alcançado e ferido por Aquiles, segundo o escoliasta de Ilíada I. 59. Se no Télefo a ação depende da fúria de Dioniso por não ser devidamente honrado (por causa da guerra?), em Aristófanes, as videiras são cortadas pelos inimigos de guerra, e a paz é trazida por Dioniso.

Eurípides, com seus mendigos e coxos, parece ser para Aristófanes o representante da nova tragédia, a que tem em si a nova Atenas com sua assembleia, que abre as portas para os estrangeiros, embaixadores trapaceiros, oradores com retórica de mendigos. O Télefo parece ter sido inspirado especialmente em Odisseu, que também se disfarçara de mendigo para enfrentar inimigos e para pedir a ajuda dos feácios, revelando, depois, a sua identidade. Odisseu e Télefo são heróis mitológicos que, pelo seu talento, trazem em sua caracterização um prenúncio do homem político da Atenas do século V. Eurípides é a renovação, ele se contrapõe a Ésquilo que vestia seus heróis com roupas e discursos de acordo com o seu caráter elevado; o novo tragediógrafo atribui caráter aos seus personagens de acordo com o traje e os hábitos.

\section{O mito de Télefo}

Télefo, herói grego e rei dos mísios, traz em seu mito uma identificação dúbia que potencializa sua releitura pela tragédia, especialmente na exploração de cenas de reconhecimento. $\mathrm{O}$ mito de Télefo contém pontos de convergência com o de Perseu, Édipo, Filoctetes, Heracles, Teseu, entre outros. Antes de nascer, já haviam previsto que mataria os tios maternos, por isso teria sido exposto pelo avô Aleu, rei de Tégea, como Teseu por Acrísio. Mas diferentemente do matador da Górgona, teve como pai o grande filho de Zeus, Heracles, e não o próprio deus dos deuses. Seguindo ainda o mesmo mito, de acordo com a tradição épica, teria sido colocado numa arca junto com sua mãe, Auge, sacerdotisa da deusa Atena, para morrer no mar. Ambos acabam chegando à Mísia. Na versão difundida pelos tragediógrafos, Náuplio, a quem Aleu entregara a filha grávida para ser afogada, vendeu-a para mercadores, e Télefo, nascendo no monte Partênio, ali fora exposto e amamentado por uma corça, de onde imaginavam que vinha seu nome, contendo, por aproximação sonora, o radical élaphos ${ }^{2}$. Pastores o recolheram e o entregaram ao rei Córito que o criou como filho; ele crescera ainda em Tégea na Arcárdia e teria matado por acidente seus tios maternos, sem conhecer a identidade deles. O oráculo de Delfos, como para o herói Édipo, está no caminho de

2 Na verdade Télefo é "o que brilha ao longe". 
sua identificação, indicando a Télefo que seja purificado na Mísia pelo rei Teutras. Ali, então, terá oportunidade de mostrar sua semelhança ao pai, quando liberta o rei da ameaça de Idas, um dos argonautas, que queria usurpar o reino mísio. Traz também um companheiro chamado Partenopeu, que com ele teria sido exposto no monte Partênio. Como prêmio por sua vitória contra o invasor, o rei Teutras dá a ele em casamento sua filha adotiva, Auge $^{3}$, do mesmo modo que Jocasta fora a recompensa do decifrador de enigmas. Ela, porém, recusando tais núpcias, leva uma espada para o leito conjugal, mas os deuses enviam uma serpente, que se interpõe entre os noivos, e eles, por inspiração divina, se reconhecem como mãe e filho, impossibilitando qualquer um dos dois terríveis crimes iminentes.

Télefo, herdeiro do reino mísio, casado com uma filha de Teutras, Argíope, é vítima da invasão dos gregos a caminho de Troia ${ }^{4}$. Teria reagido aos invasores e matado muitos deles, nomeadamente, Tersandro, rei de Tebas, filho de Polinices, mas não teve coragem de enfrentar Aquiles, que o perseguiu até Télefo ser derrubado por uma ramagem de videira, podendo, desse modo, atingi-lo de longe com sua lança. Enquanto os gregos retornarão a Argos para preparar uma nova investida, a ferida de Télefo não cicatrizará, a não ser com a intervenção do que o feriu, de acordo com um oráculo.

Ésquilo, Sófocles e Eurípides criaram tragédias sobre este herói, das quais só temos os títulos e/ou escassos fragmentos. De Ésquilo há peças chamadas Mísios e Télefo, onde talvez já se exploraria a figura de Orestes como refém ${ }^{5}$; Sófocles teria escrito Mísios e Syllogos Akhaion. Na probabilidade de a produção sofocliana ser anterior à de Eurípides, este certamente já dialoga com as demais versões do mito. O Télefo de Eurípides recai no episódio da cura do ferimento do rei mísio por Aquiles, que se deu por ocasião do ataque dito equivocado dos gregos à Mísia, em vez da Frígia. Télefo, na tragédia homônima de 438 a.C., aparece disfarçado de mendigo diante dos gregos, em Áulis, onde de novo se reúnem para nova partida contra Tróia; consegue falar a eles, ao usar o bebê Orestes, como refém, e, depois de se identificar como grego, por prometer ensinar-lhes o caminho certo para o reino de Príamo.

3 Que, em outras versões, casou-se com o rei Teutras ao chegar à Mísia. Cf. Apolodoro, Biblioteca, II, 7.4, por exemplo.

4 Télefo teria se casado com uma filha de Príamo, para ser considerado seu filho por aliança; também aparece o nome de Hiera como sua esposa, que teria morrido na invasão dos gregos, quando lutava contra eles.

5 Segundo o escoliasta de Acarnenses 332. (Platter, 2007, p. 149). 


\section{O Télefo de Eurípides}

Talvez a inovação de Eurípides na sua versão de Télefo possa mesmo ter sido a utilização do disfarce de mendigo. Aristófanes inova ainda mais quando faz de seu Télefo um pedinte das próprias roupas em trapos ao criador de mendigos e coxos. Para chegar ao disfarce de Télefo, há uma enumeração de várias outras personagens vestidas de trapo: Eneu, Fênix, Filoctetes, Belerofonte, que tornam Télefo o mais miserável dentre os miseráveis. É interessante notarmos que tais peças aqui enunciadas não chegaram até nós, de modo que não podemos fazer uma análise da crítica da comédia acerca da criação de mendigos e coxos por Eurípides. Embora o aspecto do exagero apontado seja do trágico, o mais miserável, mais digno de piedade, o que nos parece é que o exagero do disfarce do desafortunado mendigo Télefo pode ter sido a causa da crítica aristofânica, uma vez que a comédia vai cuidar de exagerar ainda mais tais traços para despi-lo completamente de tragicidade.

O coro de acarnenses, cidadãos do demo ático de Acarnes, um dos mais prejudicados pelas incursões inimigas, quer matar o homem que fez as pazes individuais com os peloponésios, destruidores de suas vinhas. Diceópolis consegue a permissão para se defender, depois de ameaçar "matar" um cesto de carvão, principal produto da Acarnes, numa paródia ao Télefo de Eurípides, que, na peça do mesmo nome, consegue permissão para falar ao exército inimigo grego, usando o pequeno Orestes, filho do rei Agamêmnon, como refém. Para seu discurso, porém, que envolve a defesa dos espartanos, na justificativa das tréguas individuais, Diceópólis vai a Eurípides pedir os trapos de Télefo, que, sendo rei da Mísia, havia se disfarçado de mendigo, para causar piedade aos gregos.

Numa comédia, para fazer uma defesa polêmica, seria preciso encontrar uma máscara no gênero sério, a tragédia, para que tal discurso fosse investido de solenidade, causando compaixão, e ainda usando de retórica sofística. Aproveitando, desse modo, a ocasião para satirizar Eurípides, o mestre das soluções fantásticas. E o riso estaria garantido pela paródia trágica.

\section{DICEÓPOLIS}

Mas tenho muito que temer. Pois os modo

Dos lavradores conheço eu, eles ficam muito alegres,

Se pra eles e pra cidade fizer elogio algum

Homem enrolão, com justiça ou sem ela.

E aí nem se dão conta que estão sendo é vendidos;

E dos velhos também conheço as almas que

Não põem a vista noutra coisa mas só em morder com voto. 
Euzim aqui sei o que sofri nas mãos do Cléon

Por causa da comédia do ano passado.

Pois tendo me arrastado pr'o tribunal

Ele me caluniava e cuspia mentiras contra mim

Era um Cicloboro e me banhava, que por muito pouco

Não morri afogado na merdalhada de insultos.

Agora então antes de falar deixe primeiro

Que eu me vista como o mais miserável de todos. (enskeuásasthaí m' hoîon athliótaton (vv.370-84) .

Aristóteles nos informa na Poética XIII que compaixão está relacionada com o infeliz indigno de sê-lo, no entanto ao observarmos a passagem anterior, onde ele afirma que não causa compaixão um homem bom passar da felicidade para a infelicidade, notamos que este sentimento está atrelado ao de temor, que, segundo o filósofo, está relacionado ao semelhante desditoso. Na Retória II. 5 quando trata das emoções, Aristóteles define compaixão de forma mais aprofundada e a relaciona ao infeliz sem o merecer e também ao semelhante desditoso. Por que Télefo seria, para Aristófanes, o mais miserável dos miseráveis? Veremos que não se trata bem de uma definição aristotélica da compaixão, mas muito mais da utilização de artefatos por Eurípides e de Eurípides por Aristófanes como recurso para os seus devidos fins trágico e cômico, respectivamente.

Diceópólis bate à porta de Eurípídes e é recebido por seu escravo, de quem tem uma primeira impressão da sabedoria do mestre, afirmando que Eurípides está em casa e não está, pois "A mente está fora recolhendo versinhos e não está em casa, mas ele está e de pés para o alto compõe uma tragédia." (vv.398-400). Eurípides é o mestre de tornar possíveis as coisas impossíveis, graças ao deus ex machina. Para Strauss (Strauss, 1993, 80-81), ele não desce de sua posição para receber Diceópólis. A tragédia não pode se misturar à comédia, pois ela não pode conter versos retirados da comédia, enquanto esta deve conter os da tragédia. A comédia é essencialmente precedida pela tragédia. E ela é o mais eficiente disfarce da sabedoria, pois a paródia de um herói trágico em farrapos é um disfarce ainda melhor que o próprio herói trágico.

\section{DICEÓPOLIS}

Tu compões de pés pra cima,

Podendo compor de pés no chão, por isso tu compões coxos.

6 Nossa tradução de Acarnenses. 
Mas por que tu vestes os farrapos da tragédia, Roupas de dá dó? Por isso tu compões mendigos.

Mas, te peço, pelos teus joelhos, Eurípides,

Dá pra mim um farrapo daquela peça antiga;

Pois tenho que falar pro coro uma tirada grande.

Ela traz a morte, se eu falar mal. (410-417)

Diceópolis quer a roupa que o torne o mais lamentável, o mais digno de piedade, athliótatos. Eurípides, então, passa a perguntar que roupas são essas (vv. 418-434):

\section{EURÍPIDES}

Quais trapos? Acaso aqueles com que aqui Eneu

O coitado do velho concorria?

\section{DICEÓPOLIS}

De Eneu não era, era de outro mais miserável.

\section{EURÍPIDES}

Os de Fênix, o ceguinho?

\section{DICEÓPOLIS}

Não de Fênix, não.

Havia outro mais miserável que Fênix.

\section{EURÍPIDES}

Que mantos esfarrapados o homem me pede?

Será que falas dos de Filoctetes, o mendigo?

\section{DICEÓPOLIS}

Dele não, de um muito, muito mais mendigo.

\section{EURÍPIDES}

Acaso queres os mantos sujos

Que Belerofonte tinha, este coxo aqui?

\section{DICEÓPOLIS}

Não era Belerofonte. Mas também o tipo era

Coxo pedinte tagarela bom de lábia.

\section{EURÍPIDES}

Sei quem é o homem, o mísio Télefo.

\section{DICEÓPOLIS}

É isso, Télefo.

Dele me dá, eu te suplico, os farrapos.

\section{EURÍPIDES}

Ó rapaz, dá-lhe os trapos do Télefo.

Estão por cima dos trapos do Tiestes

No meio dos de Ino. Aqui tens, toma lá. 
Os trapos de Télefo estavam sobre os de Tiestes e misturados aos de Ino, cuja infelicidade talvez fosse próxima à de Télefo. Diceópolis precisa das roupas de tal personagem de Eurípides, por se encontrar em situação semelhante: tendo que conseguir a clemência de inimigos, seja para se curar de uma ferida ou para poder permanecer com sua paz particular, ambos devem defender pactos com inimigos dos seus interlocutores.

Após ter conseguido os farrapos de Télefo, Diceópolis faz uma prece a Zeus (435-36), para que vista a roupa mais miserável que exista (enskeuásasthai m' hô̂on athliótaton). E passa a pedir os acessórios dos farrapos: primeiro, o chapelinho mísio, explicando que tem que ser um mendigo e não apenas parecer. E conclui afirmando que os espectadores saberão quem ele é, mas o coro será enganado por seu palavreado (440-44). Ao ouvir essas palavras, Eurípides o elogia, dizendo que mostra finura de espírito e sutileza de ideias.

E passa a assumir o caráter de mendigo, pedindo na sequência: um cajado de mendigo, um cestinho bem passado pelas brasas, uma escudela que esteja embeiçada, uma panelinha com uma esponja dentro, umas folhas de couve para por no cestinho, o cerefólio da mãe de Eurípides. A cada pedido, Eurípides vai se irritando mais e dizendo que Diceópolis está levando embora toda a sua tragédia, numa crítica ao teatro de Eurípides dependente de artefatos.

Pretendendo obter a confiança do grande público, principalmente composto de verdadeiros acarnenses, pois ele se disfarça de Télefo diante dos espectadores, tomando-os como cúmplices contra os supostos acarnenses do coro, Diceópólis se dirige ao público e não ao coro, falando como mendigo e como poeta cômico (Acarnenses 496 ss):

\section{DICEÓPOLIS}

Não vão ficar com raiva, espectadores,

Se eu sendo um mendigo na frente dos atenienses

Esteja pra falar sobre a cidade, fazendo uma comédia;

Pois o que é justo a comédia também conhece.

E eu vou falar coisas terríveis, mas justas;

Pois desta vez não vai me caluniar Cléon que

Estrangeiros estando aqui eu falo mal da cidade;

É que estamos sós, é o concurso das Leneias,

E os estrangeiros não estão aqui...

No seu discurso, Diceópólis fala à cidade sobre a cidade. Havia fracassado na Assembléia como simples agricultor, então é agora o poeta cômico, pois fala 
numa comédia. Um só homem não pode se opor a toda uma cidade, a não ser com extrema humildade. Há uma oposição muito grande entre o caráter diminuto do indivíduo e a grandeza da cidade e o que ela representa, que são as coisas justas (cf. Strauss, 1993, 82).

No discurso de defesa, Diceópolis-Télefo (497-556) começa pedindo desculpas por ser um mendigo e falar diante de atenienses sobre coisas justas; Télefo diria o mesmo em relação aos mais nobres gregos (Fr. 703). Quando Lâmaco aparece para socorrer a metade do coro que o chama, Diceópolis-Télefo treme por causa de suas armas, como Télefo teria tremido diante de Aquiles na ocasião do ferimento. E Lâmaco que parece desempenhar nesta cena o papel de Aquiles, que traz a guerra de uma forma pavorosa, expressa pelo despertar da Górgona, pergunta como um mendigo se atreve a falar sobre assuntos da cidade, fazendo com que Diceópolis revele sua identidade de cidadão e, portanto, com direito a falar sobre a cidade, do mesmo modo que Télefo teria revelado seu disfarce e sua origem grega para Aquiles, na tragédia de Eurípides. Há ainda a referência da motivação da guerra ter sido os raptos das prostitutas, que resultaram no decreto de Mégara. Télefo poderia ter feito a defesa de Troia, apontando outros raptos sem maiores consequências, contrastando com o de Helena, que origina a guerra de Troia, do mesmo modo que o rapto das prostitutas de Aspásia, em Acarnenses, provocaria a fúria de Péricles, que troveja como Zeus.

Segundo Foley (1996, p. 135), Aristófanes faz paródia da tragédia de Eurípides, em primeiro lugar, para a defesa da crítica social e política da comédia. Ao relacionar sua comédia à tragédia euripidiana, ele reclama para ela "a mesma autoridade moral, prestígio literário e amplitude" que o público sempre atribuiu aos gêneros mais elevados; em segundo lugar, o poeta cômico quer criar uma audiência diferenciada para suas comédias: que perceba as alusões mais sutis a Eurípides, antes de expor tão explicitamente o tragediógrafo no palco, i.e., antes de revelar tão explicitamente os mecanismos de sua paratragédia. Aristófanes usa o contraste entre gêneros para definir seu próprio gênero cômico. A comédia viola deliberadamente os limites trágicos, e tal violação torna-se a base de sua própria defesa, de sua proposta de discurso livre, de verdade e de justiça.

Por outro lado, já notamos que o disfarce do Télefo de Eurípides parece ter sido exagerado, pelo menos para a tragédia. Voelke (2002, p.4), apontando as semelhanças existentes entre o Eurípides aristofânico e os próprios protagonistas da comédia de Aristófanes, alerta-nos para a utilização do termo trygoidía por Diceópolis-Télefo, isto é, por um disfarce de personagem de Eurípides. Supondo, 
com isso, que o termo pode se referir à tragédia euripidiana, que estaria numa proximidade do gênero cômico, destacando-se da tragoidía. Em vez de autoridade à comédia, o disfarce de Télefo traria uma "desautoridade" da tragédia de Eurípides?

Poderemos também ler o termo trygoidía como a mistura feita por Aristófanes com a tragédia de Eurípides, que seria uma união dos dois gêneros dramáticos? ainda mais quando percebemos que o que faz a comédia de Aristófanes em relação à tragédia de um modo geral é trasformar o sangue do sacrifício no vinho do banquete, isto é, o tragos "bode ou vítima" é substituído por tryx, trygos "borra de vinho". E Eurípides com suas saídas fantásticas serve como um artifício dentro da comédia aristofânica, que se salva através dele. A leitura que fazemos da tragédia de Eurípides como artifício da comédia aristofânica será muito mais evidente, após a análise do que se passa em Tesmoforiantes.

\section{Tesmoforiantes}

É o próprio Eurípides que, dessa vez, precisa de um disfarce e um discurso eficientes para se defender e evitar a morte. As mulheres que celebram as Tesmofórias, naquele ano, decidirão o destino do poeta inimigo do gênero feminino. E o poeta, como não poderia deixar de ser, já tem um plano que tenta colocar em prática. Como Diceópolis, que foi à casa de Eurípides pedir emprestado os trajes de Télefo, disfarçado de mendigo, embora fosse um rei, o tragediógrafo vai à casa de Agatão, também poeta trágico, mas efeminado, pois veste-se de mulher, com a desculpa de que faz um drama feminino. Eurípides procura Agatão para que entre no Tesmofórion, templo interdito aos homens, e fale, se preciso for, em sua defesa diante das mulheres. Com a recusa de Agatão, que não quer atritos com o gênero de sua mímesis, será o parente por aliança de Eurípides, identificado normalmente como Mnesíloco, sogro do poeta, mas que preferimos não nomear, uma vez que o importante é o parentesco, e o anonimato poderia sugerir algo mais: ou uma matéria amorfa para a criação euripidiana do feminino ou, quem sabe, a confirmação da consciência do parentesco de Eurípides com a comédia, pois o parente será o bufão da comédia nessa primeira parte.

7 Cf. o epíteto cunhado pelo poeta cômico Cratino: euripidaristofanizante.

8 Cf. Cavaleiros, em que o sangue de touro como suicídio é substituído por vinho de inspiração salvadora; Lisístrata, o sacrifício juramento substitui o sangue de uma vítima por vinho de um odre degolado; e Tesmoforiantes, onde o bebê- refém é na verdade um odre disfarçado. 
A transformação do parente em mulher é bem indicadora do artifício do teatro de Eurípides, quando saltam à vista as inúmeras personagens femininas do poeta: Medeia, Ifigênia, Electra, Helena, Hécuba, Fedra, entre outras. Os trajes femininos serão fornecidos pelo poeta efeminado Agatão, numa clara manifestação do caráter artificial ou indireto de tal disfarce, em vez de uma mulher, será um travesti, assim como todas as personagens femininas do teatro trágico, já que não havia atrizes. Em Aristófanes, notaremos que a mulher será um artifício do poeta para continuar a "falar mal da cidade ou dos homens da cidade" sem a censura política. Pois nessa peça veremos que há um poeta que poderá morrer por "falar mal das mulheres". Aristófanes poderia ser condenado se numa época de golpe oligárquico como era aquela, falasse mal de homens reais da cidade.

Os meses que antecedem o estabelecimento do regime dos 400 são de medo e agitação. Para Casevitz (1996, 93-101), a ficção dramática é inspirada na realidade e assim o processo literário representa o processo político. Na verdade a peça traz um clima tenso de aflição para o poeta trágico ameaçado de morte pelas mulheres, que fazem uma assembleia no meio das festividades. $\mathrm{O}$ autor nos aponta como prova de seu argumento por um disfarce de realidade, o vocabulário de medo, que, de modo geral, expressa: a perseguição de um ímpio, violação, traição, espionar, revelar segredos, tudo estendido a todos os suspeitos de trair a cidade. As mulheres seriam o disfarce, pois a peça veste roupas femininas para falar do sentimento de terror da época de forma a não levantar suspeitas. O vocabulário desta peça é bem semelhante ao de Lisístrata. Há muitas palavras que só aparecem em Aristófanes nessas duas peças, fortalecendo a afirmação de que foram compostas proximamente. Entre tais palavras, está parrhesia (540-3), que, etimologicamente, significa "palavra livre" "sinceridade", o seu significado é considerado próprio da democracia. Casevitz (99) nos informa que tal palavra só aparece no século V, durante a guerra do Peloponeso e somente em Eurípides (oito exemplos desde $\mathrm{Hi}$ pólito (428) até Bacantes). Era uma espécie de argumento de propaganda ateniense, onde reinava a liberdade, sobrepondo-se a Esparta, onde a palavra era servil. $\mathrm{Na}$ segunda metade da guerra, passou a ser utilizada na política interna ateniense.

Ora, em Tesmoforiantes, nós assistimos a uma verdadeira retirada da máscara do teatro, numa crítica aos fundamentos da representação séria, a trágica, por utilizar atores homens em papéis femininos, ficando o ridículo manifesto pelo travestimento, no palco, do parente de Eurípides em uma velha mulher. O parente de Eurípides será o novo Télefo, pois disfarçado falará em favor do poeta diante de suas inimigas naturais, as mulheres. Quando se vê em apuros, usa o mesmo artifício do refém: agora um bebê de uma das mulheres do Tesmofórion, que, na verdade, 
é um odre de vinho disfarçado. Esta cena é fundamental na peça, pois além de relacionar Tesmoforiantes com Acarnenses e ambas com Télefo (cf. Platter, 2007, p. 143-175; cf. Silva, 2011, p.11-35), apresenta a transformação cômica de um sacrifício sangrento em vinho festivo. Embora a situação do parente não melhore com tal artifício, abrem-se possibilidades para novas paródias de Eurípides.

Bowie, em seu livro Aristophanes Mith, ritual and comedy, no capítulo dedicado à Tesmoforiantes, sugere que Aristófanes faz, nessa peça, uma demarcação de limites à tragédia de Eurípides, que teria incorporado traços cômicos especialmente nas duas peças mais recentes, Helena e Andrômeda. Aristófanes usa técnicas similares às de Eurípides para comprovar que a comédia tem maior flexibilidade e potencial para submeter a tragédia e suas convenções a uma crítica radical. Assim faz, nessa peça, a paródia de todo um dia do festival, com três tragédias, um drama satírico e uma comédia (Télefo, Palamedes, Helena e Andrômeda, que mesmo não sendo um drama satírico, é trasformada em um pelo comediógrafo, e uma peça cômica obscena com uma dançarina e um guarda) (Bowie, 1993, p. 217-225).

Percebemos que, depois da parábase, que fez a defesa feminina, temos a paródia de Helena, peça considerada a retratação de Eurípides para com Helena, divinizada pelos espartanos. Depois de tê-la ofendido duramente nas peças As troianas e Hécuba, como a responsável pela destruição de Tróia, Eurípides tenta se desculpar, trazendo uma Helena de outra versão do mito. Ela não teria ido a Tróia com Páris, mas o seu eidolon é que foi, enganando a todos. Helena mesma tinha ficado presa no Egito, onde o rei queria desposá-la à força, e Menelau, voltando da guerra, a encontra, reconhecem-se e voltam para Esparta. Na paródia de Andrômeda, o disfarce do parente conta com um coadjuvante, a Ninfa Eco, que parece ser representada pelo mesmo ator que faz o papel de Eurípides, talvez só com a voz. O interessante da cena é que as repetições das últimas palavras dos interlocutores pela Ninfa é semelhante ao processo mimético da comédia em relação à tragédia de Eurípides, pelo menos no que diz respeito à Helena, quando há quase completa repetição do texto de poeta trágico com pequenas modificações.

\section{Rãs}

Outra vez um disfarce da tragédia de Eurípides será utilizado, Héracles. É através dele, movido pelo desejo de Eurípides, que Dioniso irá ao Hades resgatar o tragediógrafo. O disfarce é o do herói mais corajoso de todos, que irá ao Hades trazer o cão Cérbero para o rei Euristeu. Dioniso é bem o inverso de seu meio-irmão, pois suas características são mais femininas e covardes, trazendo ao pensamento do 
espectador a figura de Agatão de Tesmoforiantes, quando se apresentava como uma mistura de homem-mulher. Dioniso parece causar em Héracles a mesma impressão causada por Agatão no parente de Eurípides, por misturar vestes teatrais dionisíacas e femininas com o disfarce de Héracles e sua força varonil.

Rãs é a única peça de Aristófanes, em que há dois coros, que não se opõem (como acontece com os dois semicoros de Lisístrata ou com o coro de Acarnenses). E ela recebe o nome não do coro principal, de iniciados, mas do coro de rãs, que só se manifesta durante a travessia do pântano por Dioniso, no barco de Caronte. Strauss (1993, p. 304) dá a explicação de que essa dualidade coral corresponde à dualidade de terror e felicidade no Hades. O coro de rãs toma, assim, o lugar dos criminosos extremados no Hades, i.e., os adoradores de Eurípides, como percebemos pela descrição de Éaco, escravo de Plutão (771 ss.):

Ea. Quando Eurípides chegou, deu um espetáculo aos ladrões de roupa, aos batedores de carteira, aos parricidas e aos arrombadores que, aqui no Hades, formam uma multidão. E eles, assistindo às discussões, às negaças e às viradas, ficaram completamente loucos por ele que, então, foi considerado o mais hábil. Daí, Eurípides, aclamado, apoderou-se do trono onde Ésquilo estava sentado! ${ }^{9}$

Esses criminosos não teriam sido suportados como um coro que professa os mais altos princípios de injustiça, sem conversão mesmo com os castigos após a morte. Assim, o título da peça nos faz notar essa "impossibilidade potencial" (cf. Strauss, 1993, p. 304).

Ésquilo foi escolhido por Dioniso, que, em princípio, desejava ardentemente Eurípides, para a salvação da cidade. Investiguemos como um poeta é escolhido por ser o melhor para a cidade.

Eurípides introduz novas divindades e, implicitamente, contesta as estabelecidas (885-94):

Di. (aos poetas) E vocês aí façam uma oração antes de recitarem os versos!

És. Deméter, que alimentaste o meu espírito, que eu seja digno de vossos mistérios!

Di. (a Eurípides) E você toma o incenso e ofereça-o!

Eu. (recusando o incenso) Obrigado! São outros os deuses a quem dirijo as minhas preces...

9 Tradução inédita da Ana Lia de Almeida Prado e Silvia Milanezi. 
Di. São deuses só seus, de nova cunhagem?

Eu. São sim.

Di. Vamos! Reze então a esses seus deuses!

Eu. Éter, meu alimento! Móvel de minha língua! Conhecimento! Narinas sagazes! Que eu refute à altura os discursos que vou enfrentar!

Podemos encontrar um outro aspecto da impiedade de Eurípides em Tesmoforiantes $451 \mathrm{~s}$ : "mas agora este que faz tragédias persuadiu os homens de que não há deuses". A poesia de Ésquilo imita a natureza, por isso se interessa principalmente com a ética do seu conteúdo; a de Eurípides imita a imitação da natureza, por isso se interessa, primeiro, pela técnica poética, pelo realismo de seu discurso. Desse modo, Ésquilo apresenta personagens nobres, com linguagem e trajes adequados; enquanto Eurípides apresenta personagens mais próximos da realidade, e, assim, defeituosos, com linguagem e trajes correspondentes (cf. Santos, 1992/3, p.83-95). Eurípides fala da inutilidade da linguagem pomposa de Ésquilo, que se defende, dizendo que

Esq. É preciso criar falas à altura dos grandes provérbios e pensamentos. Aliás, é de se esperar que os semideuses usem falas mais imponentes, pois também usam mantos muito mais imponentes que os nossos. O que eu apresentei como útil você destruiu. ... Primeiro vestiu os reis com farrapos para que os homens parecessem dignos de piedade... Depois você ainda os ensinou a entregar-se à tagarelice e ao falatório, o que esvaziou as palestras, poliu a bunda dos mocinhos tagarelas e convenceu o pessoal do porto a contestar os chefes. ... De que males não é culpado? Esse aí não pôs em cena alcoviteiras, mulheres que dão à luz nos templos, que se unem com irmãos, que dizem que viver não é viver? É por isso que a cidade ficou cheia de escrevinhadores, de bufões, macacos do povo, que ao povo estão sempre enganando. Tocha ninguém é capaz de levar, hoje em dia, por falta de exercício. (1059-89)

Ésquilo acusa Eurípides do mesmo crime de que Dikaios Logos tinha acusado o Adikaios Logos, em Nuvens: fazer com que os cidadãos se ocupem mais de falar do que de praticar ginástica. E também de misoginia e falar mal das mulheres, de que ele é acusado em Tesmoforiantes e Lisístrata. Em Nuvens, Fidípides começa a bater no seu pai, por que ele o impede de recitar passagens de Éolo de Eurípides, cujo tema é incesto entre irmãos.

Assim como o Sócrates de Nuvens se distinguia dos dois discursos, o justo e o injusto, Dioniso e Aristófanes se diferenciam dos dois poetas, Ésquilo e Eurípides. Pois enquanto Ésquilo não cuida de Afrodite e da compaixão, Eurípides descuida da cidade ou do patriotismo guerreiro e de esconder uma verdade perniciosa. Strauss 
chama a atenção para a função edificante, representada por Ésquilo, e a corretiva do riso, de que se ocupa Aristófanes e da compaixão, atribuída a Eurípides. No Hades, de modo diferente de Atenas, são os melhores poetas que ocupam lugar de destaque junto a Plutão. Assim, em analogia a Atenas, que dá a proedria e o alimentar-se no Pritaneu como honras a um benfeitor da pólis, podemos concluir que o bom poeta é um benfeitor tanto para a cidade de um modo geral como para a alma humana.

Dioniso é competente para julgar o melhor poeta trágico, então também o seria para julgar a sabedoria política. Ele pune com justiça Eurípides por sua negação dos deuses dando o prêmio para Ésquilo. Age semelhante às Nuvens: com justiça (Nuvens 1462) .

A peça Rãs apresenta a educação de Dioniso, o educador de Aristófanes, que vai da admiração sem limite por Eurípides a uma preferência por Ésquilo. Tal educação se dá em um Hades inteiramente ateniense. $\mathrm{O}$ coro, no final da peça, parece fazer uma equivalência entre Eurípides e Sócrates, contrastando este último com Ésquilo.

\section{Conclusão}

As três peças analisadas apresentaram uma cena de travestimento com a procura de um adjuvante que emprestasse as roupas, Eurípides e Agatão, ou que indicasse o caminho, Héracles. Todas são relacionadas com personagens de Eurípides, que servem como artifício para a salvação proposta pela comédia. Em Acarnenses, parece ser o poeta cômico quem está em apuros e precisa de Télefo para se defender diante do coro de velhos do demo de Acarnes; em Tesmoforiantes, é o próprio Eurípides que deve pedir perdão às mulheres, através de suas próprias peças parodiadas por um parente cômico e, em Rãs, será o desejo do deus do teatro pelo poeta Eurípides que o levará ao resgate da tragédia de Ésquilo como proposta de salvação da cidade em guerra.

\section{REFERÊNCIAS Bibliográficas}

Aristophane. Les acharniens, les cavaliers, lês nuées (Cinquième édition revue et corrigée) (Texte établi par Victor Coulon et traduit par Hilaire Van Daele) Paris: Les Belles Lettres, 1952.

Aristophane. Acharnians (Edited with introduction and commentary by S. Douglas Olson) Oxford, 2002. 
ARISTÓFAnes. As mulheres que celebram as Tesmofórias. Introdução, versão do grego e notas de Maria de Fátima Silva. Edições 70, 2001.

. As Rãs. Tradução inédita de Ana Lia de Almeida Prado e Silva Milanezi.

- Os acarnenses (Introdução, versão do grego e notas de Maria de Fátima de Sousa e Silva) Coimbra: Instituto Nacional de Investi.gação Científica, 1980.

Bowie, A. M. Myth, ritual and comedy. Cambridge Universuty Press, 1996 (first published 1993).

Casevitz, Michel. La politique dans les Thesmophories d' Aristophane: à propos du vocabulaire. Cahier du Gita, n. 9, 93-101,1996.

Foley, Helene P. Tragedy and politics in Aristophanes' Acharnians. JHS, 108. p.3347, 1988.

Platter, Charles. Aristophanes and the carnival of genres. Johns Hopkins. 2007.

SAntos, Marcos Martinho dos. A teoria literária aristofânica. Clássica $5 / \&$, São Paulo, 1992/3, p. 83-95.

Strauss, Leo. Socrate et Aristophane. Traduit de l'anglais et présenté par Olivier Sedeyn. LÉclat, 1993. (Collection "Polemos"), (1ª edição 1966).

VoelKe, Pierre. Euripide, héros et poète comique : à propos des Acharniens et des Thesmophories d'Aristophane. In: CALAME, Claude. Poétique d'Aristophane et langue d'Euripide en dialogue. Editions Etudes de Lettres, 2005. (http:// chs.harvard.edu/wa/pageR?tn $=$ ArticleWrapper\&bdc $=12 \& m n=3664)$

Abstract: In Acharnians Aristophanes to serve the Telephus of Euripides to defend himself as a poet and as a comic actor, such a model will be resumed in Thesmophoriazusae, the need for a new outfit, the feminine. Again when the tragedy was in Hades, and the city needed a bailout, the god Dionysus was disguised as Herakles to rescue Euripides, which, although replaced by Aeschylus, is still the motivation of the rescue of the tragedy in the world of the dead, in Frogs. Aristophanes, criticizing and assimilating the tricks of the tragedy by Euripides, the poet of the many solutions, sets the limits of his comedy and is distinguished as a poet and thinker in the Athens of the second half of the fifth century.

Keywords: Euripides, Aristophanes, Telephus, Disguise, tricks. 